\title{
PENGEMBANGAN RENCANA PELAKSANAAN PEMBELAJARAN (RPP) TEMATIK BERBASIS KARAKTER
}

\author{
Fathia Fairuza Hanum ${ }^{1} \&$ Suprayekti ${ }^{2}$ \\ e-mail: fathiafairuza.hanum@gmail.com ${ }^{1}$, suprayekti8@gmail.com ${ }^{2}$ \\ Program Studi Teknologi Pendidikan Universitas Negeri Jakarta \\ Jalan Rawamangun Muka, RT.11/RW.14, Rawamangun, Pulo Gadung, \\ Kota Jakarta Timur, DKI Jakarta 13220
}

\begin{abstract}
Abstrak: Penguatan Pendidikan Karakter (PPK) merupakan kebijakan pendidikan yang bertujuan untuk mengimplementasikan nilai religiusitas, nasionalisme, kemandirian, gotong royong, dan integritas. Agar dapat terimplementasi di dalam pembelajaran diperlukan pengembangan Rencana Pelaksanaan Pembelajaran (RPP) yang terintegrasi dengan nilai-nilai tersebut. Tujuan penelitian ini adalah untuk menghasilkan prototipe produk RPP tematik yang dikhususkan untuk siswa kelas 2 SD. Penelitian ini dilakukan dengan metode Research \& Development (R\&D) yang disederhanakan. Penelitian dilaksanakan dari Bulan Juni sampai Oktober 2019, bertempat di SD Muhammadiyah 24 Jakarta Timur. Validasi produk dilakukan oleh ahli dan kelompok kecil. Hasil penelitian secara umum menunjukkan bahwa kualitas prototipe yang dihasilkan berdasarkan validasi dari ahli desain pembelajaran dan ahli materi adalah sebesar $76 \%$ dan $98 \%$. Sedangkan berdasarkan hasil ujicoba skala kecil kualitas yang didapatkan adalah 90\%. Hasil tersebut menunjukkan bahwa produk prototipe RPP tematik yang dikembangkan dapat diterapkan dalam proses pembelajaran pada siswa kelas 2 SD sehingga dapat memberikan dampak pengiring yang akan menghasilkan karakter yang sesuai dengan PPK. Dan sebaiknya ada penelitian lanjutan yang akan mengembangkan produk ini menjadi lebih sempurna.
\end{abstract}

Kata-kata kunci: karakter, pengembangan, penguatan pendidikan karakter, rencana pelaksanaan pembelajaran tematik

\section{THE DEVELOPMENT OF A CHARACTER BASED THEMATIC LESSON PLAN}

\begin{abstract}
The application of Character Education (PPK) is an education policy that aims to implement the values of religiosity, nationalism, independence, mutual cooperation, and integrity. To be implemented in learning, it is necessary to develop lesson plans that are integrated with those values. The aim of this study was to produce a prototype of thematic Lesson Plan (RPP) that is specific to students in grade 2 of elementary school. This study is a simplified educational Research \& Development (RED). This study was carried out from June to October 2019, which took place at SD Muhammadiyah 24 Jakarta Timur. Product validation was done by experts and small groups. The results of the study in general show that the quality of the prototype based on the validation by instructional design and material experts were $76 \%$ and $98 \%$. Additionally, based on the small-scale trials the quality of the prototype was $90 \%$. These results indicate that the prototype of the Thematic Lesson Plan (RPP) developed can be applied in the learning process of grade 2 elementary schools' students so that it can have an accompanying impact that will produce character of religiosity, nationalism, independence, mutual cooperation and integrity in accordance with The application of Character Education (PPK). Further research is needed to perfectly develop the prototype.
\end{abstract}

Keywords: character, development, thematic lesson plan, the application of character education 


\section{PENDAHULUAN}

Pendidikan adalah sebuah usaha yang ditempuh oleh manusia untuk memperoleh ilmu yang kemudian dijadikan sebagai dasar untuk bersikap dan berperilaku. Oleh karena itu, proses pendidikan akan menghasilkan sikap dan perilaku yang akhirnya menjadi watak, kepribadian, atau karakter seorang manusia.

Menurut Thomas Lickona karakter merupakan sifat alami seseorang dalam merespons situasi secara bermoral (Wibowo, 2012). Sedangkan menurut Suyanto (Wibowo, 2012) karakter adalah cara berpikir dan berperilaku yang menjadi ciri khas tiap individu untuk hidup dan bekerja sama, baik dalam lingkup keluarga, masyarakat, bangsa dan negara. Sedangkan Scerenko (Samani \& Hariyanto, 2012) mendefinisikan karakter sebagai atribut atau ciri-ciri yang membentuk dan membedakan ciri pribadi, ciri etis dan kompleksitas mental dari seseorang. Berdasarkan beberapa definisi tersebut dapat disimpulkan bahwa karakter adalah sifat alami seseorang yang membentuk dan membedakannya dari orang lain.

Dalam era globalisasi seperti saat sekarang ini, menjadi satu tantangan tersendiri bagi pengelola pendidikan untuk menyesuaikan kurikulum dan sarana pendidikan lainnya agar karakter ke- Indonesia -an tetap dipertahankan dan terus dikembangkan. Sejalan dengan laju perkembangan masyarakat, kurikulum pendidikan menjadi sangat dinamis dan harus menyesuaikan dengan situasi dan kondisi yang ada agar karakter masyarakat Indonesia semakin bernuansa Indonesia.

Kurikulum sebagai jantung dari proses pendidikan di Indonesia, telah mengalami beberapa kali perubahan dan yang terahir adalah Kurikulum 2013. Pada kurikulum 2013, proses pembelajaran yang dituntut adalah pembelajaran yang berpusat pada pembelajaran tematik untuk siswa Sekolah Dasar, yang menggabungkan antara mata pelajaran satu dengan pelajaran lainnya. Selain itu proses pembelajaran menurut kurikulum 2013 sangat memperhatikan taraf berfikir siswa yang masih memandang sesuatu merupakan satu bagian yang utuh dan tidak terpisahkan. Pada kurikulum 2013 siswa diharapkan belajar melalui pengalaman langsung.

Pembelajaran tematik bagi murid sekolah dasar disesuaikan dengan tingkatan kelas yang ada di sekolah dasar. Menurut Supandi (Kawuryan, 2017) tingkatan kelas di sekolah dasar dapat dibagi menjadi dua, yaitu kelas rendah dan kelas tinggi. Kelas rendah terdiri dari kelas satu, dua, dan tiga, sedangkan kelaskelas tinggi terdiri dari kelas empat, lima, dan enam. Di Indonesia, rentang usia siswa SD, yaitu antara 6 atau 7 tahun sampai 12 tahun. Usia siswa pada kelompok kelas rendah, yaitu 6 atau 7 sampai 8 atau 9 tahun. Siswa yang berada pada kelompok ini termasuk dalam rentangan anak usia dini. Masa usia dini ini merupakan masa yang pendek tetapi sangat penting bagi kehidupan seseorang. Oleh karena itu, pada masa ini seluruh potensi yang dimiliki anak perlu didorong sehingga akan berkembang secara optimal.

Menurut Surya dkk (2018) usia peserta didik kelas rendah adalah masa peralihan dari masa kanakkanak. Pada masa ini sebagian besar peserta didik masih belum bisa terbiasa gaya belajar pendidikan formal. Oleh sebab itu, sistem pembelajaran pada kelas rendah menggunakan tema dengan penanaman pembiasaan kebiasaan baik, penanaman karakter, dan pengenalan lingkungan sekitar peserta didik.

Kawuryan (2017) menyatakan bahwa pembelajaran di kelas rendah dilaksanakan berdasarkan rencana pelajaran yang telah dikembangkan oleh guru. Proses pembelajaran harus dirancang guru sehingga kemampuan siswa, bahan ajar, proses belajar, dan sistem penilaian sesuai dengan tahapan perkembangan siswa. Hal lain yang harus dipahami, yaitu proses belajar harus dikembangkan secara interaktif. Dalam hal ini, guru memegang peranan penting dalam menciptakan stimulus respon agar siswa menyadari kejadian di sekitar lingkungannya. Siswa kelas rendah masih banyak membutuhkan perhatian karena fokus konsentrasinya masih kurang, perhatian terhadap kecepatan dan aktivitas belajar juga masih kurang. Hal ini memerlukan kegigihan guru dalam menciptakan proses belajar yang lebih menarik dan efektif.

Selain itu, siswa sekolah dasar baik di kelas rendah dan tinggi, menurut Piaget (Djiwandono, 2006) berada pada tahap operasi konkret, dimana mereka telah dapat berpikir logis namun masih memerlukan hal-hal yang konkret dalam kehidupan sehari-harinya. Mereka masih sangat realistik, sehingga dalam proses pembelajaran, seorang guru harus pintar dalam memilih model, strategi, ataupun pendekatan yang tepat agar proses pembelajaran yang berlangsung dapat menarik dan siswa bisa mendapatkan pengalaman belajar yang tepat.

Berdasarkan karakteristik yang dimiliki oleh siswa sekolah dasar kelas rendah, maka siswa kelas 2 Sekolah Dasar (SD) bisa menjadi role model yang mencerminkan karakteristik siswa kelas rendah secara utuh. Siswa kelas 2 sekolah dasar juga sudah lepas 
dari proses pembelajaran di Pendidikan Anak Usia Dini (PAUD) dan bersiap menikmati kemerdekaan mereka menjadi siswa sekolah dasar. Maka sistem pembelajaran tema dengan penanaman karakter pada kelas rendah dapat tercermin secara utuh pada proses pembelajaran di kelas 2 .

Pendidikan karakter menurut Wibowo (2012) adalah suatu sistem penanaman nilai-nilai karakter kepada warga sekolah, yang meliputi komponen pengetahuan, kesadaran atau kemauan dan tindakan untuk melaksanakan nilai-nilai tersebut. Menurut Winton (Samani \& Hariyanto, 2012) pendidikan karakter adalah upaya secara sadar dan sungguhsungguh dari seorang guru untuk mengajarkan nilainilai kepada para siswanya. Menurut Burke (Samani \& Hariyanto, 2012) pendidikan karakter didefinisikan sebagai pendidikan yang mengembangkan karakter mulia (good character) dari peserta didik dengan mempraktikkan dan mengajarkan nilai-nilai moral dan pengambilan keputusan yang beradab dalam hubungannya dengan sesama manusia maupun dalam hubungannya dengan Tuhannya.

Penguatan Pendidikan Karakter (PPK) merupakan kebijakan pendidikan yang tujuan utamanya adalah adanya perubahan cara berpikir, bersikap, dan bertindak menjadi lebih baik. Nilainilai utama PPK adalah religiusitas, nasionalisme, kemandirian, gotong royong, integritas. Nilai-nilai ini ingin ditanamkan dan dipraktikkan melalui sistem pendidikan nasional agar diketahui, dipahami, dan diterapkan di seluruh sendi kehidupan yang ada di sekolah dan di masyarakat. PPK lahir karena kesadaran akan tantangan ke depan yang semakin kompleks dan tidak pasti, namun sekaligus melihat ada banyak harapan bagi masa depan bangsa. Hal ini menuntut lembaga pendidikan untuk mempersiapkan peserta didik secara keilmuan dan kepribadian, sebagai individu-individu yang kokoh dalam nilainilai moral, spiritual dan keilmuan.

Dari fungsi dan tujuan yang ingin dicapai, Penguatan Pendidikan Karakter (PPK) tidak hanya merupakan inovasi pendidikan, tetapi juga merupakan reformasi pendidikan yang harus dipersiapkan dan dilaksanakan dengan benar serta melibatkan setiap pihak yang terkait dengan penyelenggaraan pendidikan. Sebagai upaya dalam mengimplementasikan nilai-nilai utama PPK di dalam proses pembelajaran diperlukan langkah konkret yakni pengintegrasian Rencana Pelaksanaan Pembelajaran (RPP) tematik dengan nilai-nilai utama PPK.

Rencana Pelaksanaan Pembelajaran (RPP) merupakan penjabaran silabus menjadi satuan-satuan kegiatan pembelajaran yang secara operasional agar dapat dilaksanakan oleh guru. Untuk itu guru harus mampu mengembangkan Rencana Pelaksanaan Pembelajaran (RPP) tematik secara tepat yang terintegrasi dengan nilai-nilai utama PPK. Sehingga secara aktif siswa dapat mengembangkan potensi dirinya, melakukan proses internalisasi, dan penghayatan nilai-nilai menjadi kepribadian mereka dalam bergaul di masyarakat. Yang selanjutnya karakter tersebut akan mengembangkan kehidupan masyarakat yang lebih sejahtera, serta mengembangkan kehidupan bangsa yang bermartabat di kemudian hari.

Berdasarkan latar belakang tersebut maka penelitian pengembangan prototipe Rencana Pelaksanaan Pembelajaran (RPP) tematik berbasis karakter menurut nilai-nilai utama Penguatan Pendidikan Karakter (PPK) untuk siswa kelas 2Sekolah Dasar ini dilakukan. Prototipe Rencana pelaksanaan Pembelajaran (RPP) berbasis karakter adalah produk yang berisi rencana terkait dengan pembelajaran untuk satu kali pertemuan atau lebih yang dibuat secara terperinci mengacu pada kompetensi tertentu dan mengkoordinasikan komponen pembelajaran sebagai upaya secara sadar dan sungguh-sungguh dalam mengembangkan nilai-nilai moral dan karakter mulia di dalam diri seorang siswa yang dikembangkan.

\section{METODE PENELITIAN}

Metode penelitian yang digunakan dalam penelitianinimerupakan penelitian dan pengembangan. Langkah dalam penelitian dan pengembangan ini merupakan modifikasi atau penyederhanaan langkah penelitian dan pengembangan menurut Sugiyono (2018). Langkah-langkah penelitian dan pengembangan yang dilakukan adalah: (1) mengidentifikasi masalah: melakukan observasi mengenai penerapan program Penguatan Pendidikan Karakter (PPK) dan hubungannya dengan Rencana Pelaksanaan Pembelajaran (RPP), (2) merencanakan penelitian: menganalisis kurikulum dan silabus, mencari referensi terkait metode pembelajaran yang inovatif dan materi kelas 2 Sekolah Dasar (SD) yang akan diintegrasikan dengan nilai nilai utama PPK, (3) pengembangan produk: tahap ini peneliti melakukan perencanaan desain RPP dan membuat produk awal RPP yang akan dikembangkan, (4) validasi ahli: hasil dari perencanaan dan pengembangan produk akan dinilai atau divalidasi oleh ahli desain pembelajaran dan ahli materi, (5) revisi produk: berdasarkan data validasi yang dilakukan oleh ahli dan saran yang diberikan, hal tersebut selanjutnya akan digunakan 
sebagai acuan dalam merevisi produk, (6) uji coba skala kecil: hasil revisi produk selanjutnya digunakan dalam uji coba produk dalam skala kecil. Dalam hal ini akan diuji coba kepada guru-guru tingkat Sekolah Dasar di SD Muhammadiyah 24 sebanyak 6 orang, dan (7) produk akhir: data hasil uji coba skala kecil akan dijadikan acuan untuk merevisi produk secara final, setelah direvisi maka produk akhir yang dihasilkan adalah Rencana Pelaksanaan Pembelajaran (RPP) tematik berbasis karakter menurut nilai-nilai utama Penguatan Pendidikan Karakter (PPK) untuk siswa kelas 2 Sekolah Dasar.

Penelitian ini dilakukan di sebuah SD di Jakarta Timur sebagai tempat uji coba empirik atau penilaian terhadap prototipe produk. Durasi penelitian juga relatif pendek yakni selama 5 bulan dari bulan Juni hingga Oktober 2019. Instrumen penelitian pada penelitian ini dibuat menjadi 3 jenis yang digunakan untuk mengevaluasi dan memvalidasi produk yang dibuat sehingga produk yang dihasilkan pada penelitian ini layak dan valid untuk digunakan. Instrumen tersebut yaitu: (1) Instrumen uji kelayakan untuk ahli desain pembelajaran, (2) Instrumen uji kelayakan untuk ahli materi, (3) Instrumen uji coba untuk kelompok kecil pada guru. Ketiga instrumen tersebut berbentuk angket/kuesioner tertutup dengan bentuk checklist.

Hasil dari pengembangan Rencana Pelaksanaan Pembelajaran (RPP) pada penelitian ini diharapkan akan menjadi produk yang layak baik secara kualitas ataupun isi. Oleh karena itu produk yang dikembangkan telah melalui proses validasi oleh ahli dan uji coba dalam skala kecil. Setelah produk melalui proses expert judgement, hal berikutnya yang dilakukan adalah merevisi produk sesuai dengan saran dan catatan ahli dan hasil revisi produk tersebut diuji coba ke dalam skala kecil di lapangan. Uji coba instrumen di lapangan dilakukan oleh guru tingkat Sekolah Dasar (SD) sebanyak 6 orang.

Setelah data didapatkan dari ahli desain pembelajaran, ahli materi dan uji coba kelompok kecil, data kemudian ditabulasi secara kuantitatif menggunakan persentase capaian yang dibandingkan dengan kriteria tertentu seperti yang dikemukakan oleh Sugiyono (2010),

$$
\operatorname{Pr}=\frac{S C}{S I} \times 100 \%
$$

Keterangan:

$$
\begin{array}{ll}
\text { Pr } & \text { Presentasi Capaian } \\
\text { SC } & : \text { Jumlah Skor Capaian } \\
\text { SI } & : \text { Jumlah Skor Ideal }
\end{array}
$$

Langkah berikutnya adalah mengkonfirmasi persentase capaian responden dengan kategori keberhasilan dengan kualifikasi $81-100 \%$ berada pada kategori sangat baik, 61-80\% pada kategori baik, 41$60 \%$ pada kategori cukup baik, $21-40 \%$ pada kategori kurang, dan dibawah $<20 \%$ pada kategori sangat kurang. Selanjutnya revisi produk dilakukan sesuai masukan dan saran yang diberikan para ahli dan guru. Revisi ini memberikan beberapa perubahan terhadap produk yang dikembangkan, Setelah direvisi sesuai masukan dan saran dari para ahli, produk akhir dari penelitian dan pengembangan ini adalah prototipe Rencana Pelaksanaan Pembelajaran (RPP) tematik berbasis karakter menurut Penguatan Pendidikan Karakter (PPK) yang terdiri dari karakter religiusitas, karakter nasionalisme, karakter kemandirian, karakter gotong royong, dan karakter integritas.

\section{HASIL DAN PEMBAHASAN}

\section{Mengidentifikasi masalah}

Pada tahapan identifikasi masalah diperoleh informasi melalui media daring dan guru-guru Sekolah Dasar (SD) bahwa belum ada bentuk model Rencana Pelaksanaan Pembelajaran (RPP) tematik untuk kurikulum 2013 revisi 2017 yang hanya mengintegrasikan pendidikan karakter menurut nilai-nilai utama Penguatan Pendidikan Karakter (PPK) dalam tahapan proses pembelajaran. Rencana Pelaksanaan Pembelajaran (RPP) tematik yang ada masih banyak cenderung menggunakan pendekatan saintifik. Beberapa sudah mengintegrasikan nilainilai utama Penguatan Pendidikan Karakter (PPK), namun hanya saja Rencana Pelaksanaan Pembelajaran (RPP) tematik yang ada tidak hanya terintegrasi dengan nilai-nilai utama Penguatan Pendidikan Karakter (PPK) tetapi juga terintegrasi dengan pendidikan literasi, 4C (communication, collaboration, creativity, dan critical thinking) dan HOTS (High Order Thinking Skill). Berdasarkan kebutuhan tersebut maka peneliti berusaha mengembangkan model Rencana Pelaksanaan Pembelajaran (RPP) tematik berbasis nilai-nilai utama Penguatan Pendidikan Karakter (PPK) ke dalam bentuk sebuah prototipe.

\section{Merencanakan penelitian}

Merencanakan penelitian adalah menyimpulkan data/bahan yang dapat dijadikan informasi yang nantinya menjadi rencana dalam mengembangkan Rencana Pelaksanaan Pembelajaran (RPP) tersebut. Perencanaan dan pengembangan Rencana Pelaksanaan Pembelajaran (RPP) dalam penelitian ini dibuat sebaik dan setepat mungkin sesuai dengan standar proses 
dalam Permendikbud Nomor 22 tahun 2016 yang disesuaikan dengan kebutuhan, yakni untuk siswa tingkatSekolah Dasar (SD). Peneliti juga menggunakan buku guru dan buku siswa pada Kurikulum 2013 revisi 2017 sebagai referensi dalam merencanakan dan mengembangkan Rencana Pelaksanaan Pembelajaran (RPP) dalam penelitian ini.

\section{Pengembangan produk}

Pada tahap pengembangan awal produk yang dihasilkan adalah draf produk Rencana Pelaksanaan Pembelajaran (RPP). Adapun gambaran draf produk pengembangan RPP sebagai berikut:

\section{PROTOTIPE RENCANA PELAKSANAAN PEMBELAJARAN (RPP) TEMATIK BERBASIS KARAKTER MENURUT PENGUATAN PENDIDIKAN KARAKTER (PPK): \\ 1. RELIGIUS \\ 2. NASIONALIS \\ 3. MANDIRI \\ 4. GOTONG ROYONG \\ 5. INEGRITAS}

\begin{tabular}{|c|c|}
\hline & (RPP) \\
\hline Sekolah & $: \operatorname{SDN}[\ldots]$ \\
\hline Kelas/Semester & $:$ II/I \\
\hline Tema 1 & : Hidup Rukun \\
\hline Sub Tema 1 & : Hidup Rukun di Rumah \\
\hline Pembelajaran Ke- & $: 1$ \\
\hline Alokasi Waktu & $: 6 \times 35$ menit $(6 \mathrm{jpl})$ \\
\hline
\end{tabular}

\section{A. Kompetensi Inti (KI)}

1. Menerima dan menjalankan ajaran agama yang dianutnya

2. Memiliki perilaku jujur, disiplin, tanggung jawab, santun, peduli, dan percaya diri dalam berinteraksi dengan keluarga, teman dan guru

3. Memahami pengetahuan faktual dengan cara mengamati (mendengar, melihat, membaca) dan menanya berdasarkan rasa ingin tahu tentang dirinya, makhluk ciptaan Tuhan dan kegiatannya, dan benda-benda yang dijumpainya di rumah dan sekolah sekolah.

4. Menyajikan pengetahuan faktual dalam bahasa yang jelas dan logis dan sistematis, dalam karya yang estetis dalam gerakan yang mencerminkan anak sehat, dan dalam tindakan yang mencerminkan perilaku anak beriman dan berakhlak mulia
B. Kompetensi Dasar (KD) dan Indikator Pencapaian Kompetensi

Bahasa Indonesia

\begin{tabular}{cc}
$\begin{array}{c}\text { Kompetensi Dasar } \\
\text { (KD) }\end{array}$ & $\begin{array}{c}\text { Indikator Pencapaian } \\
\text { Kompetensi }\end{array}$ \\
\hline
\end{tabular}

3.1 Merinci ungkapan, $\mathrm{M}$ e $\mathrm{n}$ y e b u t $\mathrm{k}$ a $\mathrm{n}$ ajakan, perintah, ungkapan yang penolakan yang terdapat dalam teks terdapat dalam teks cerita.

cerita atau lagu yang menggambarkan sikap hidup rukun.

4.1 Menirukan Mengucapkan ungkapan, ajakan, ungkapan yang perintah, penolakan terdapat dalam teks dalam cerita atau lagu percakapan. anak-anak dengan bahasa yang santun.

\begin{tabular}{|c|c|}
\hline \multicolumn{2}{|l|}{ Matematika } \\
\hline $\begin{array}{c}\text { Kompetensi Dasar } \\
\text { (KD) }\end{array}$ & $\begin{array}{c}\text { Indikator Pencapaian } \\
\text { Kompetensi }\end{array}$ \\
\hline $\begin{array}{l}\text { 3.1 Menjelaskan } \\
\text { makna bilangan cacah } \\
\text { dan menentukan } \\
\text { l a m b a g y a } \\
\text { berdasarkan nilai } \\
\text { tem pat dengan } \\
\text { menggunakan model } \\
\text { konkret serta cara } \\
\text { membacanya. }\end{array}$ & $\begin{array}{l}\text { Menyatakan kumpulan } \\
\text { objek/ benda dengan } \\
\text { bila ngan s a mpai } \\
\text { dengan } 999 \text {. }\end{array}$ \\
\hline $\begin{array}{l}4.1 \text { Membaca dan } \\
\text { menyajikan bilangan } \\
\text { cacah dan lambangnya } \\
\text { berdasarkan nilai } \\
\text { tem pat dengan } \\
\text { menggunakan model } \\
\text { konkret. }\end{array}$ & $\begin{array}{l}\text { Membaca lambang } \\
\text { bilangan sampai } \\
\text { dengan } 999 \text {. }\end{array}$ \\
\hline
\end{tabular}

SBdP

Kompetensi Dasar Indikator Pencapaian (KD) Kompetensi

3.2Mengenal pola irama Membedakan panjang sederhana melalui lagu dan pendek bunyi pada anak-anak. lagu anak-anak.

4.2 Menampilkan Menampilkan panjang pola irama sederhana dan pendek bunyi pada melalui lagu anak-anak. lagu anak-anak.

C. Tujuan Pembelajaran

1. Siswa kelas 2 dapat menyebutkan ungkapan yang terdapat dalam teks cerita dengan teliti setelah mendapatkan bimbingan dari guru.

2. Siswa kelas 2 dapat mengucapkan ungkapan yang terdapat dalam teks percakapan dengan benar setelah membaca teks cerita dan teks percakapan. 
3. Siswa kelas 2 dapat menyatakan kumpulan objek/ benda dengan bilangan sampai dengan 999 dengan benar setelah mendapat bimbingan dari guru.

4. Siswa kelas 2 dapat membaca lambang bilangan sampai dengan 999 dengan tepat setelah mendapat penugasan dari guru.

5. Siswa kelas 2 dapat membedakan panjang dan pendek bunyi pada lagu anak-anak dengan tepat setelah menyimak lagu yang dinyanyikan oleh guru.

6. Siswa kelas 2 dapat menampilkan panjang dan pendek bunyi pada lagu anak-anak dengan tepat setelah bersama-sama menyanyikan lagu bersama guru.

\section{Media Pembelajaran dan Sumber Belajar}

1. Buku Siswa Tema "Hidup Rukun" Kelas 2 (Buku Tematik Terpadu Kurikulum 2013 Rev.2017, Jakarta: Kementerian Pendidikan dan Kebudayaan, 2013 Rev.2017).

2. Teks lagu "Peramah dan Sopan"

3. Alat Peraga "Stik Es Krim"

4. Teks Bacaan

\section{E. Metode Pembelajaran}

Ceramah, penugasan, diskusi, tanya jawab, simulasi

\section{F. Kegiatan Pembelajaran}

\begin{tabular}{|c|c|c|c|}
\hline $\begin{array}{l}\text { Ke- } \\
\text { gia- } \\
\text { tan }\end{array}$ & Deskripsi Kegiatan & $\begin{array}{l}\text { Karak- } \\
\text { ter yang } \\
\text { Dikem- } \\
\text { bangkan }\end{array}$ & $\begin{array}{c}\text { Alo- } \\
\text { kasi } \\
\text { Wak- } \\
\text { tu } \\
\end{array}$ \\
\hline \multirow{6}{*}{ 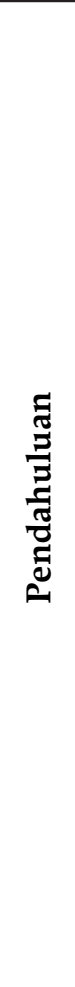 } & $\begin{array}{l}\text { 1. Kelas dibuka } \\
\text { dengan salam }\end{array}$ & $\frac{\text { Sopan }}{\text { Santun }}$ & $\begin{array}{c}15 \\
\text { Menit }\end{array}$ \\
\hline & $\begin{array}{l}\text { 2. Guru menanya- } \\
\text { kan kabar siswa }\end{array}$ & $\frac{\text { Kepe- }}{\text { dulian }}$ & \\
\hline & $\begin{array}{l}\text { 3. Kelas dimu- } \\
\text { lai dengan doa } \\
\text { menurut agama } \\
\text { dan kepercayaan } \\
\text { masing-masing }\end{array}$ & Religius & \\
\hline & $\begin{array}{l}\text { yang dipimpin } \\
\text { oleh salah seo- } \\
\text { rang siswa. }\end{array}$ & & \\
\hline & $\begin{array}{l}\text { 4. Guru memberi- } \\
\text { kan bimbingan } \\
\text { mengenai pent- } \\
\text { ingnya memulai } \\
\text { sesuatu dengan } \\
\text { berd oa. Guru } \\
\text { juga memberikan } \\
\text { penguatan men- } \\
\text { genai pentingnya } \\
\text { bersyukur. }\end{array}$ & Religius & \\
\hline & $\begin{array}{l}\text { 5. Guru mengecek } \\
\text { kehadiran siswa }\end{array}$ & $\begin{array}{l}\text { Kepe- } \\
\text { dulian }\end{array}$ & \\
\hline
\end{tabular}

\begin{tabular}{|c|c|c|c|}
\hline $\begin{array}{l}\text { Ke- } \\
\text { gia- } \\
\text { tan }\end{array}$ & Deskripsi Kegiatan & $\begin{array}{l}\text { Karak- } \\
\text { ter yang } \\
\text { Dikem- } \\
\text { bangkan }\end{array}$ & $\begin{array}{c}\text { Alo- } \\
\text { kasi } \\
\text { Wak- } \\
\text { tu }\end{array}$ \\
\hline \multirow{3}{*}{ 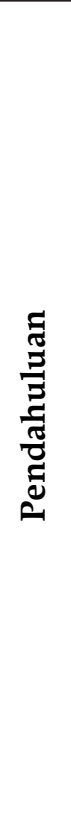 } & $\begin{array}{l}\text { 6. Siswa diajak men- } \\
\text { yanyikan lagu } \\
\text { Indonesia Raya, } \\
\text { lagu-lagu nasion- } \\
\text { al dan menanam- } \\
\text { kan semangat ke- } \\
\text { bangsaan kepada } \\
\text { siswa. }\end{array}$ & $\begin{array}{c}\text { Nasion- } \\
\text { alis }\end{array}$ & $\begin{array}{c}15 \\
\text { Menit }\end{array}$ \\
\hline & $\begin{array}{l}\text { 7. Siswa diminta } \\
\text { memerika kera- } \\
\text { pihan diri dan ke- } \\
\text { bersihan ruangan } \\
\text { kelas. }\end{array}$ & $\begin{array}{c}\text { Tanggung } \\
\text { Jawab }\end{array}$ & \\
\hline & $\begin{array}{l}\text { 8. Guru member- } \\
\text { ikan penjelasan } \\
\text { mengenai tujuan, } \\
\text { dan manfaat dari } \\
\text { aktivitas pembe- } \\
\text { lajaran yang akan } \\
\text { dilakukan. }\end{array}$ & $\begin{array}{l}\text { Rasa } \\
\text { Ingin } \\
\text { Tahu }\end{array}$ & \\
\hline
\end{tabular}

1. Guru mengarahkan siswa untuk mengamati gambar yang ada pada Buku Siswa

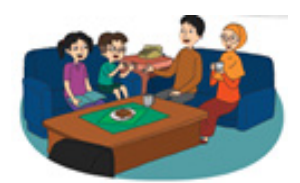

2. Guru bertanya jawab kepada siswa mengenai kerukunan di rumah yang tercermin dalam gambar tersebut.

3. Siswa menuliskan jawaban pertanyaan yang ada di Buku Siswa di selembar kertas.

$\begin{array}{cc}\text { Teliti } & 175 \\ & \text { Menit }\end{array}$

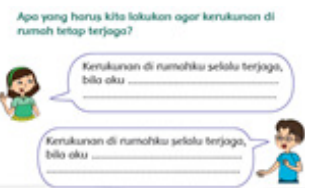

4. Kertas jawaban dikumpulkan, lalu secara bergantian siswa membaca jawaban temannya.

5. Guru menanggapi jawaban siswa tersebut. 


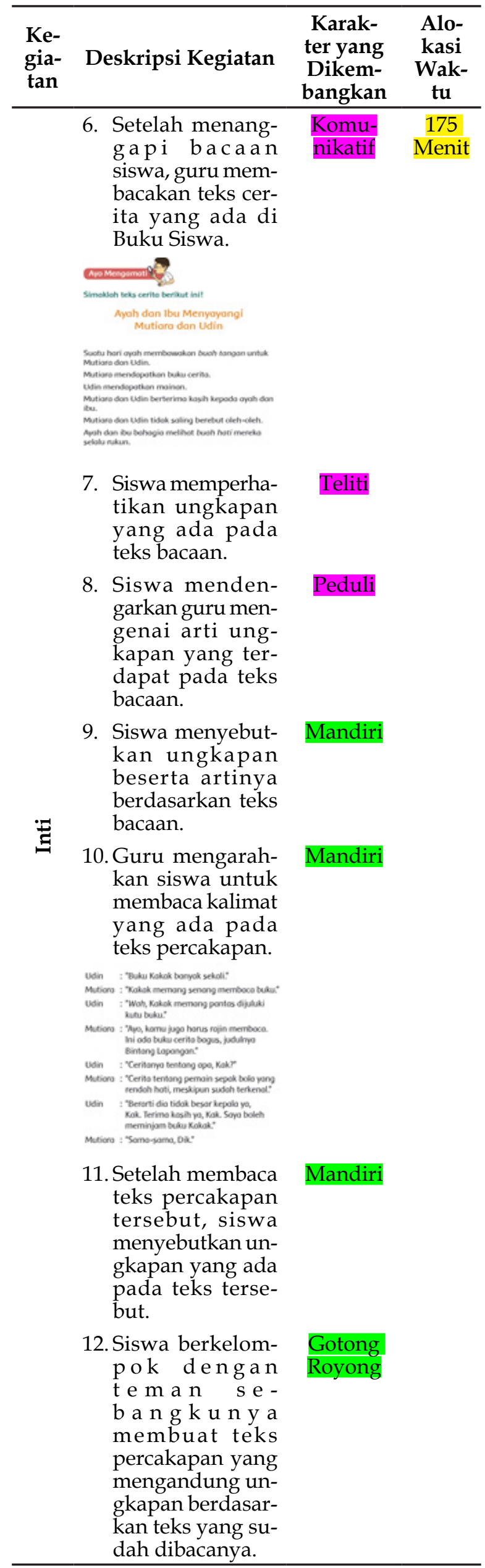

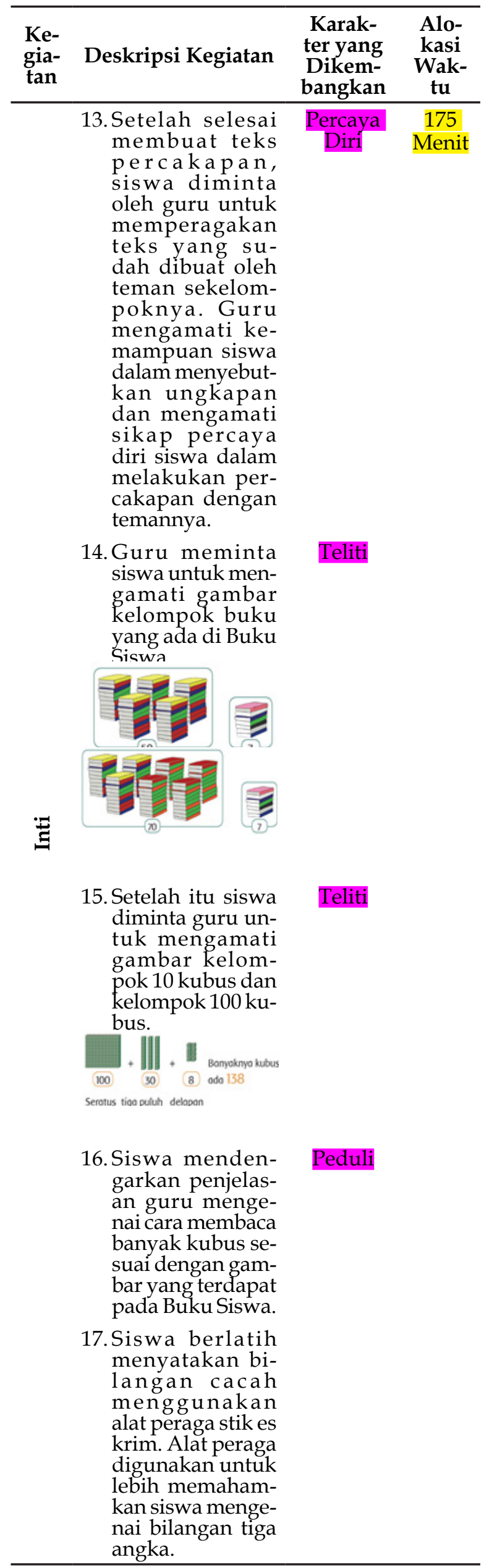




\begin{tabular}{|c|c|c|c|c|c|c|c|}
\hline $\begin{array}{l}\text { Ke- } \\
\text { gia- } \\
\text { tan }\end{array}$ & Deskripsi Kegiatan & $\begin{array}{l}\text { Karak- } \\
\text { ter yang } \\
\text { Dikem- } \\
\text { bangkan }\end{array}$ & $\begin{array}{l}\text { Alo- } \\
\text { kasi } \\
\text { Wak- } \\
\text { tu }\end{array}$ & $\begin{array}{l}\text { Ke- } \\
\text { gia- } \\
\text { tan }\end{array}$ & Deskripsi Kegiatan & $\begin{array}{c}\text { Karak- } \\
\text { ter yang } \\
\text { Dikem- } \\
\text { bangkan }\end{array}$ & $\begin{array}{c}\text { Alo- } \\
\text { kasi } \\
\text { Wak- } \\
\text { tu }\end{array}$ \\
\hline & $\begin{array}{l}\text { 18. Siswa membaca } \\
\text { bilangan cacah } \\
\text { sampai } 999 . \text { Guru } \\
\text { mengamati ke- } \\
\text { mampuan siswa } \\
\text { dalam membaca } \\
\text { bilangan cacah } \\
\text { sampai } 999 .\end{array}$ & Teliti & $\begin{array}{c}175 \\
\text { Menit }\end{array}$ & 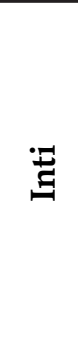 & $\begin{array}{l}\text { 25. Guru mengama- } \\
\text { ti kemampuan } \\
\text { siswa dalam men- } \\
\text { yanyikan lagu } \\
\text { Peramah dan } \\
\text { Sopan menurut } \\
\text { panjang dan } \\
\text { pendek bunyi/ } \\
\text { nada. }\end{array}$ & $\begin{array}{c}\text { Percaya } \\
\text { Diri }\end{array}$ & $\begin{array}{c}175 \\
\text { Menit }\end{array}$ \\
\hline & $\begin{array}{l}\text { 19. Siswa menyimak } \\
\text { guru menyan- } \\
\text { yikan lagu Pera- } \\
\text { mah dan Sopan. }\end{array}$ & Teliti & & \multirow{5}{*}{ 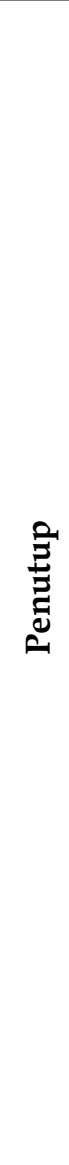 } & $\begin{array}{l}\text { 1. Guru bertanya } \\
\text { jawab dengan } \\
\text { siswa tentang } \\
\text { materi yang telah } \\
\text { dipelajari. }\end{array}$ & $\begin{array}{l}\text { Rasa } \\
\text { Ingin } \\
\text { Tahu }\end{array}$ & $\begin{array}{c}20 \\
\text { Menit }\end{array}$ \\
\hline & 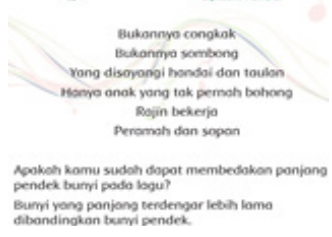 & & & & $\begin{array}{l}\text { 2. Guru bersama-sa- } \\
\text { ma dengan siswa } \\
\text { membuat kesim- } \\
\text { pulan / rangku- } \\
\text { man hasil belajar } \\
\text { selama sehari. }\end{array}$ & Integritas & \\
\hline \multirow{3}{*}{$\underset{\Xi}{\Xi}$} & $\begin{array}{l}\text { 20. Siswa diminta } \\
\text { guru untuk ikut } \\
\text { merasakan kapan } \\
\text { nada lagu din- } \\
\text { yanyikan panjang } \\
\text { dan kapan nada } \\
\text { lagu dinyanyikan } \\
\text { pendek. }\end{array}$ & Integritas & & & $\begin{array}{l}\text { 3. Guru memberi- } \\
\text { kan kesempatan } \\
\text { kepada siswa } \\
\text { untuk menyam- } \\
\text { paikan pendapat- } \\
\text { nya tentang pem- } \\
\text { belajaran yang } \\
\text { telah diikuti. }\end{array}$ & Berani & \\
\hline & $\begin{array}{l}\text { 21. Siswa bersa- } \\
\text { ma-sama dengan }\end{array}$ & \multirow{2}{*}{\multicolumn{2}{|c|}{ Integritas }} & & $\begin{array}{l}\text { 4. Guru melakukan } \\
\text { penilaian hasil } \\
\text { belajar }\end{array}$ & $\begin{array}{l}\text { Mandiri, } \\
\text { Jujur }\end{array}$ & \\
\hline & $\begin{array}{l}\text { yikan lagu Pera- } \\
\text { mah dan Sopan } \\
\text { sambil mera- } \\
\text { sakan panjang } \\
\text { dan pendeknya } \\
\text { nada. }\end{array}$ & & & & $\begin{array}{l}\text { 5. Kelas ditut- } \\
\text { up dengan doa } \\
\text { menurut agama } \\
\text { dan kepercayaan } \\
\text { masing-masing } \\
\text { yang dipimpin } \\
\text { oleh salah seo- } \\
\text { rang siswa. }\end{array}$ & Religius & \\
\hline
\end{tabular}
menandai bagian-bagian lagu yang dinyanyikan panjang dan yang dinyanyikan pendek.

23. Siswa dibimbing guru untuk memahami panjang pendek bunyi melalui notasi lagu Peramah dan Sopan..

24. Siswa mengamati guru ketika memberikan contoh menyanyikan bagian panjang pendek lagu yang disesuaikan dengan notasinya.

\section{G. Penilaian}

1. Teknik Penilaian

a.Penilaian Sikap $\quad$ : Lembar Observasi

b.Penilaian Pengetahuan : Tes

c. Penilaian Keterampilan : Unjuk Kerja

Mandiri

2. Bentuk Instrumen Penilaian

a.Sikap

Indikator untuk Penilaian Sikap

\begin{tabular}{lll}
\hline $\begin{array}{c}\text { Karakteryang } \\
\text { Dikembang- } \\
\text { kan }\end{array}$ & Definisi & Indikator \\
\hline Religius & $\begin{array}{l}\text { Keberiman- } \\
\text { an terhadap } \\
\text { Tuhan yang } \\
\text { Maha Esa. }\end{array}$ & $\begin{array}{l}\text { Melaksanakan } \\
\text { ajaran agama } \\
\text { dan keper- } \\
\text { cayaan yang } \\
\text { dianut. }\end{array}$ \\
& & $\sqrt{ } \begin{array}{l}\text { Menghargai } \\
\text { perbedaan ag- } \\
\text { ama. }\end{array}$ \\
\hline
\end{tabular}




\begin{tabular}{|c|c|c|c|}
\hline & & $\begin{array}{l}\sqrt{ } \\
\\
\sqrt{ }\end{array}$ & $\begin{array}{l}\text { Menjunjung } \\
\text { tinggi sikap } \\
\text { toleransi ter- } \\
\text { hadap pelak- } \\
\text { sanaan ibadah } \\
\text { agama dan } \\
\text { kepercayaan } \\
\text { lain. } \\
\text { Bersyukuratas } \\
\text { nikmat Tuhan } \\
\text { YME }\end{array}$ \\
\hline Nasionalis & $\begin{array}{l}\text { Cara berpikir, } \\
\text { bertindak, dan } \\
\text { berwawasan } \\
\text { yang menem- } \\
\text { patkan kepent- } \\
\text { ingan bangsa } \\
\text { dan negara di } \\
\text { atas kepentin- } \\
\text { gan diri dan } \\
\text { kelompoknya. }\end{array}$ & $\sqrt{ }$ & $\begin{array}{l}\text { Memiliki se- } \\
\text { mangat ke- } \\
\text { bangsaan. } \\
\text { Mampubeker- } \\
\text { jasama dengan } \\
\text { teman yang } \\
\text { berbeda suku, } \\
\text { etnis dan sta- } \\
\text { tus s o s i a l } \\
\text { ekonomi. }\end{array}$ \\
\hline Mandiri & $\begin{array}{l}\text { Sikap dan } \\
\text { perilaku yang } \\
\text { tidak mudah } \\
\text { tergantung } \\
\text { pada orang } \\
\text { lain dalam } \\
\text { menyelesaikan } \\
\text { tugas-tugas. }\end{array}$ & $\begin{array}{l}\sqrt{ } \\
\sqrt{ } \\
\sqrt{ } \\
\sqrt{ }\end{array}$ & $\begin{array}{l}\text { Percaya akan } \\
\text { kemampuan } \\
\text { sendiri dan ti- } \\
\text { dak menyon- } \\
\text { tek. } \\
\text { Yakin akan } \\
\text { setiap tugas } \\
\text { yang dikerja- } \\
\text { kan sendiri. } \\
\text { Tidak takut } \\
\text { untuk bertan- } \\
\text { ya. } \\
\text { Tidak ber- } \\
\text { gantung pada } \\
\text { orang lain. }\end{array}$ \\
\hline $\begin{array}{l}\text { Gotong } \\
\text { Royong }\end{array}$ & $\begin{array}{l}\text { Mencermink- } \\
\text { an tindakan } \\
\text { menghargai } \\
\text { semangat kerja } \\
\text { samadan bahu } \\
\text { m e m b a h u } \\
\text { menyelesaikan } \\
\text { persoalan ber- } \\
\text { sama. }\end{array}$ & $\sqrt{ }$ & $\begin{array}{l}\text { Aktif dalam } \\
\text { kerja kelom- } \\
\text { pok } \\
\text { Tidak menda- } \\
\text { h u l u k a n } \\
\text { kepentingan } \\
\text { pribadi } \\
\text { Kesediaa n } \\
\text { melaksanakan } \\
\text { tugas sesuai } \\
\text { kesepakatan. }\end{array}$ \\
\hline Integritas & $\begin{array}{l}\text { Nilai yang } \\
\text { mendasari } \\
\text { perilaku yang } \\
\text { didasarkan } \\
\text { pada upaya } \\
\text { menjadikan } \\
\text { dirinya sebagai } \\
\text { orang yang } \\
\text { selalu dapat } \\
\text { dipercaya da- } \\
\text { lamperkataan, } \\
\text { tindakan dan } \\
\text { pekerjaan. }\end{array}$ & $\begin{array}{l}\sqrt{ } \\
\sqrt{ }\end{array}$ & $\begin{array}{l}\text { Dapat diper- } \\
\text { caya dalam se- } \\
\text { tiap tindakan } \\
\text { dan perkataan } \\
\text { Selalu bersikap } \\
\text { jujur } \\
\text { M e m i l i k i } \\
\text { komitmen da- } \\
\text { lam mengerja- } \\
\text { kan tugas. }\end{array}$ \\
\hline
\end{tabular}

Lembar Pengamatan/Observasi Bulan: 2019

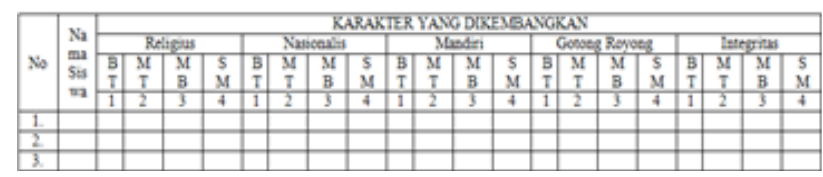

Keterangan:

BT : BELUM TERLIHAT (Skor 1)

MT : MULAI TERLIHAT (Skor 2)

MB : MULAI BERKEMBANG (Skor 3)

SM :SUDAH MEMBUDAYA (Skor 4)

b.Pengetahuan dan Keterampilan

Rubrik Penilaian

1. Bahasa Indonesia

Rubrik Penilaian Mengucapkan Ungkapan di dalam Teks

\begin{tabular}{|c|c|c|c|c|}
\hline \multirow{2}{*}{$\begin{array}{l}\text { Aspek/ } \\
\text { Kriteria }\end{array}$} & \multicolumn{4}{|c|}{ Skor } \\
\hline & 4 & 3 & 2 & 1 \\
\hline $\begin{array}{l}\text { Penge- } \\
\text { tahuan: } \\
(\mathrm{KD} 3.1 \text { ) } \\
\text { ketepatan } \\
\text { me- } \\
\text { nyebut- } \\
\text { kan } \\
\text { ungkapan } \\
\text { di dalam } \\
\text { teks }\end{array}$ & $\begin{array}{l}\text { S e m u a } \\
\text { ungkapan } \\
\text { di dalam } \\
\text { teks dise- } \\
\text { butkan } \\
\text { dengan } \\
\text { be na r, } \\
\text { t a n p a } \\
\text { bantuan } \\
\text { guru. }\end{array}$ & $\begin{array}{l}\text { Ada be- } \\
\text { berapa } \\
\text { ungkapan } \\
\text { di dalam } \\
\text { teks yang } \\
\text { m a s i h } \\
\text { salah } \\
\text { disebut- } \\
\text { kan, } \\
\text { t a n p a } \\
\text { bantuan } \\
\text { guru. }\end{array}$ & $\begin{array}{l}\text { Ada be- } \\
\text { berapa } \\
\text { ungkapan } \\
\text { di } \\
\text { d a } 1 \text { a m } \\
\text { teks yang } \\
\text { m a s i h } \\
\text { salah } \\
\text { disebut- } \\
\text { kan, } \\
\text { dengan } \\
\text { bantuan } \\
\text { guru. }\end{array}$ & $\begin{array}{l}\text { B e } 1 \text { u m } \\
\text { ada } \\
\text { ungkapan } \\
\text { yang } \\
\text { disebut- } \\
\text { kan } \\
\text { den ga n } \\
\text { benar } \\
\text { meskipun } \\
\text { dengan } \\
\text { bantuan } \\
\text { guru. }\end{array}$ \\
\hline $\begin{array}{l}\text { K e t e r - } \\
\text { ampilan: } \\
\text { (KD 4.1) } \\
\text { ketepatan } \\
\text { meng u - } \\
\text { capkan } \\
\text { ungkapan } \\
\text { di dalam } \\
\text { teks }\end{array}$ & $\begin{array}{l}\text { Semua } \\
\text { ungkapan } \\
\text { di } \\
\text { d a l a m } \\
\text { teks } \\
\text { diucap- } \\
\text { kan } \\
\text { de n g a n } \\
\text { benar, } \\
\text { t a n p a } \\
\text { bantuan } \\
\text { guru. }\end{array}$ & $\begin{array}{l}\text { Ada be- } \\
\text { berapa } \\
\text { ungkapan } \\
\text { di } \\
\text { d a } 1 \text { a m } \\
\text { teks yang } \\
\text { m a s i h } \\
\text { salah } \\
\text { diucap- } \\
\text { kan, } \\
\text { t a n p a } \\
\text { bantuan } \\
\text { guru. }\end{array}$ & $\begin{array}{l}\text { Ada be- } \\
\text { berapa } \\
\text { ungkapan } \\
\text { di } \\
\text { d a } 1 \text { a m } \\
\text { teks yang } \\
\text { m a s i h } \\
\text { salah } \\
\text { diuca p- } \\
\text { kan, } \\
\text { dengan } \\
\text { bantuan } \\
\text { guru. }\end{array}$ & $\begin{array}{l}\text { B e } 1 \text { u m } \\
\text { ada } \\
\text { ungkapan } \\
\text { yang } \\
\text { diucap- } \\
\text { kan } \\
\text { den ga n } \\
\text { benar } \\
\text { meskipun } \\
\text { dengan } \\
\text { bantuan } \\
\text { guru. }\end{array}$ \\
\hline
\end{tabular}

2. Matematika

Rubrik Penilaian Membaca Bilangan Sampai 999

\begin{tabular}{|c|c|c|c|c|}
\hline \multirow{2}{*}{$\begin{array}{l}\text { Aspek/ } \\
\text { Kriteria }\end{array}$} & \multicolumn{4}{|c|}{ Skor } \\
\hline & 4 & 3 & 2 & 1 \\
\hline $\begin{array}{l}\text { Pengeta- } \\
\text { huan: } \\
\text { (KD 3.1) } \\
\text { ketepatan } \\
\text { men y a - } \\
\text { takan } \\
\text { bilangan } \\
\text { tiga } \\
\text { a n g k a , } \\
\text { minimal5 }\end{array}$ & $\begin{array}{l}\text { Semua bi- } \\
\text { langan } \\
\text { d in y a - } \\
\text { takan } \\
\text { dengan } \\
\text { benar. }\end{array}$ & $\begin{array}{l}\text { Ada satu } \\
\text { bilangan } \\
\text { yang } \\
\text { d i n y a - } \\
\text { takan } \\
\text { m a s i h } \\
\text { salah. }\end{array}$ & $\begin{array}{l}\text { Ada dua } \\
\text { bilangan } \\
\text { yang } \\
\text { d i n y a - } \\
\text { takan } \\
\text { m a s i h } \\
\text { salah. }\end{array}$ & $\begin{array}{l}\text { Ada tiga } \\
\text { atau lebih } \\
\text { bilangan } \\
\text { yang } \\
\text { d i n y a - } \\
\text { takan } \\
\text { m a s i h } \\
\text { salah. }\end{array}$ \\
\hline $\begin{array}{l}\text { K e t e r - } \\
\text { ampilan: } \\
\text { (KD 4.1) } \\
\text { ketepatan } \\
\text { membaca } \\
\text { bilangan } \\
\text { tiga } \\
\text { a n g k a , } \\
\text { minimal } 5 \\
\text { bilangan }\end{array}$ & $\begin{array}{l}\text { Semua bi- } \\
\text { langan } \\
\text { d i b a c a } \\
\text { dengan } \\
\text { benar. }\end{array}$ & $\begin{array}{l}\text { Ada be- } \\
\text { berapa } \\
\text { bilangan } \\
\text { yang } \\
\text { m a s i h } \\
\text { salah } \\
\text { dibaca, } \\
\text { tanpa } \\
\text { bantuan } \\
\text { guru. }\end{array}$ & $\begin{array}{l}\text { Ada be- } \\
\text { berapa } \\
\text { bilangan } \\
\text { yang } \\
\text { m a s i h } \\
\text { salah } \\
\text { dibaca, } \\
\text { dengan } \\
\text { bantuan } \\
\text { guru. }\end{array}$ & $\begin{array}{l}\text { B e l u m } \\
\text { ada } \\
\text { bilangan } \\
\text { yang } \\
\text { d i b a c a } \\
\text { dengan } \\
\text { b e n a r, } \\
\text { meskipun } \\
\text { dibantu } \\
\text { guru. }\end{array}$ \\
\hline
\end{tabular}




\section{SBdP}

Rubrik Penilaian Menampilkan Panjang Pendek Bunyi pada Lagu

\begin{tabular}{|c|c|c|c|c|}
\hline \multirow{2}{*}{$\begin{array}{l}\text { Aspek/ } \\
\text { Kriteria }\end{array}$} & \multicolumn{4}{|c|}{ Skor } \\
\hline & 4 & 3 & 2 & 1 \\
\hline $\begin{array}{l}\text { Pengeta- } \\
\text { huan: } \\
\text { (KD 3.2) } \\
\text { ketepatan } \\
\mathrm{m} \text { e n - } \\
\text { gidentifi- } \\
\text { kasi } \\
\text { panjang } \\
\text { pendek } \\
\text { b u n y i } \\
\text { pada lagu }\end{array}$ & $\begin{array}{l}\text { Dapat } \\
\text { menentu- } \\
\text { kan } \\
\text { b u n y i } \\
\text { panjang } \\
\text { danbunyi } \\
\text { pend ek } \\
\text { pada } \\
\text { l a g u , } \\
\text { semua } \\
\text { b e n a r, } \\
\text { tanpa } \\
\text { bantuan } \\
\text { guru. }\end{array}$ & $\begin{array}{l}\text { Ada be- } \\
\text { berapa } \\
\text { bagian } \\
\text { lagu yang } \\
\text { m a s i h } \\
\text { salah } \\
\text { diidentifi- } \\
\text { kasi } \\
\text { b u n y i } \\
\text { pendek } \\
\text { dan bunyi } \\
\text { panjang- } \\
\text { nya, } \\
\text { t a n p a } \\
\text { bantuan } \\
\text { guru. }\end{array}$ & $\begin{array}{l}\text { Ada be- } \\
\text { berapa } \\
\text { bagian } \\
\text { lagu yang } \\
\text { m a s i h } \\
\text { salah } \\
\text { diidentifi- } \\
\text { kasi } \\
\text { b u n y i } \\
\text { pendek } \\
\text { dan bunyi } \\
\text { panjang- } \\
\text { nya, } \\
\text { dengan } \\
\text { bantuan } \\
\text { guru. }\end{array}$ & $\begin{array}{l}\text { B e } 1 \text { u m } \\
\text { ada yang } \\
\text { benar da- } \\
\text { lam } \\
\text { menentu- } \\
\text { kan } \\
\text { b u n y i } \\
\text { panjang } \\
\text { dan bunyi } \\
\text { p e n d e k } \\
\text { lagu, } \\
\text { meskipun } \\
\text { dengan } \\
\text { bantuan } \\
\text { guru. }\end{array}$ \\
\hline $\begin{array}{l}\text { K e t e r - } \\
\text { ampilan: } \\
\text { (KD 4.2) } \\
\text { ketepatan } \\
\text { menam- } \\
\text { pilkan } \\
\text { panjang } \\
\text { pendek } \\
\text { b u n y i } \\
\text { p a d a } \\
\text { lagu. }\end{array}$ & $\begin{array}{l}\text { S e m u a } \\
\text { nada } \\
\text { dinyan- } \\
\text { yikan } \\
\text { sesuai ira- } \\
\text { ma } \\
\text { lagu den- } \\
\text { gan } \\
\text { memerha- } \\
\text { tikan } \\
\text { panjang } \\
\text { pendek } \\
\text { bu n yi, } \\
\text { tanpa } \\
\text { bantuan } \\
\text { guru. }\end{array}$ & $\begin{array}{l}\text { Ada be- } \\
\text { berapa } \\
\mathrm{n} \mathrm{a} \mathrm{d} \mathrm{a} \\
\text { yang } \\
\text { dinyan- } \\
\text { yikan } \\
\text { dengan } \\
\text { bunyi } \\
\text { panjang } \\
\text { dan } \\
\text { b u n y i } \\
\text { pendek } \\
\text { yang ma- } \\
\text { sih salah, } \\
\text { tanpa } \\
\text { bantuan } \\
\text { guru. }\end{array}$ & $\begin{array}{l}\text { Ada be- } \\
\text { berapa } \\
\mathrm{n} \text { a d a } \\
\text { yang } \\
\text { dinyan- } \\
\text { yikan } \\
\text { dengan } \\
\text { bunyi } \\
\text { panjang } \\
\text { dan } \\
\text { b un y i } \\
\text { pendek } \\
\text { yang ma- } \\
\text { sih } \\
\text { s a l a h, } \\
\text { dengan } \\
\text { bantuan } \\
\text { guru. }\end{array}$ & $\begin{array}{l}\text { Semua } \\
\text { nadayang } \\
\text { dinyan- } \\
\text { yikan } \\
\text { dengan } \\
\text { bunyi } \\
\text { panjang } \\
\text { dan } \\
\text { b u n y i } \\
\text { pendek } \\
\text { m a s i h } \\
\text { salah, } \\
\text { dengan } \\
\text { bantuan } \\
\text { guru }\end{array}$ \\
\hline
\end{tabular}

\begin{tabular}{|c|c|c|}
\hline \multicolumn{2}{|c|}{$\begin{array}{l}\text { Skor Maksimal Penilaian } \\
\text { Penilaian } \\
\text { Panduan Konversi Nilai } \\
\end{array}$} & $\begin{array}{l}: 100 \\
: \frac{\text { Skor yang diperoleh x } 100}{\text { Skor maksimal }}\end{array}$ \\
\hline $\begin{array}{l}\text { Konversi Nilai } \\
\text { (skala 0-100) }\end{array}$ & Predikat & Klasifikasi \\
\hline $81-100$ & A & SB (Sangat Baik) \\
\hline $66-80$ & B & B (Baik) \\
\hline $51-65$ & C & C (Cukup) \\
\hline $0-50$ & D & K (Kurang) \\
\hline
\end{tabular}

Mengetahui, Kepala SD [...]

Guru Kelas 2

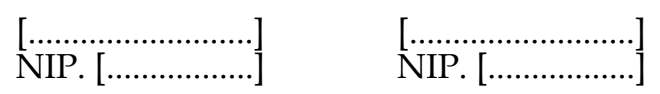

Disesuaikan dengan lembaga Karakter yang dikembangkan sesuai PPK Karakter umum yang dikembangkan

\section{Validasi ahli}

Validasi yang dilakukan untuk mengetahui kelayakan Rencana Pelaksanaan Pembelajaran (RPP) tematik untuk siswa kelas 2 Sekolah Dasar (SD) melibatkan dua orang ahli, yakni ahli desain pembelajaran dan ahli materi mengenai pembelajaran di Sekolah Dasar (SD). Adapun penjelasan validasi Rencana Pelaksanaan Pembelajaran (RPP) sebagai berikut:

\section{a. Validasi Ahli Desain Pembelajaran}

Validator yang menjadi ahli desain pembelajaran dalam penelitian ini adalah satu orang dosen prodi Teknologi Pendidikan yang memiliki pemahaman mengenai kurikulum dan desain pembelajaran. Validasi dilakukan dengan memberikan produk Rencana Pelaksanaan Pembelajaran (RPP) yang disertai dengan lembar validasi berbentuk kuesioner. Kuesioner berisi validasi mengenai aspek kualitas materi pembelajaran dan aspek isi materi dalam Rencana Pelaksanaan Pembelajaran (RPP). Validasi pada aspek kualitas materi pembelajaran terdiri dari 11 poin penilaian sedangkan validasi pada aspek isi materi pembelajaran terdiri dari 12 poin penilaian. Berikut ini adalah uraian data yang telah didapat:

Tabel 1.

Kualitas Produk Hasil Validasi Oleh Ahli Desain Pembelajaran

\begin{tabular}{ccc}
\hline No & Aspek yang Dinilai & Persentase \\
\hline 1 & Kualitas & $77 \%$ \\
2 & Isi & $75 \%$ \\
\hline \multicolumn{3}{c}{ Rata-rata Persentase } \\
Kategori & $76 \%$ \\
& Baik \\
\hline
\end{tabular}

Hasil penilaian dari ahli desain pembelajaran untuk aspek kualitas materi pembelajaran diperoleh persentase $77 \%$ dan kategori Baik. Sedangkan pada aspek isi materi pembelajaran diperoleh persentase $75 \%$ dan kategori Baik. Berdasarkan hasil penilaian dari aspek kualitas dan isi yang dilakukan oleh ahli desain pembelajaran diperoleh rata-rata persentase sebesar 76\% dengan kategori baik.

\section{b. Validasi Ahli Materi}

Validator yang menjadi ahli materi dalam penelitian ini adalah satu orang kepala sekolah di SD Muhammadiyah 24 Jakarta Timur yang memiliki pemahaman mengenai materi pembelajaran di tingkat Sekolah Dasar (SD) terkhusus untuk siswa kelas 2. Validasi dilakukan dengan memberikan produk Rencana Pelaksanaan Pembelajaran (RPP) yang disertai dengan lembar validasi berbentuk 
kuesioner. Kuesioner berisi validasi mengenai aspek kualitas materi pembelajaran dan aspek isi materi dalam Rencana Pelaksanaan Pembelajaran (RPP). Validasi pada aspek kualitas materi pembelajaran terdiri dari 11 poin penilaian sedangkan validasi pada aspek isi materi pembelajaran terdiri dari 13 poin penilaian. Berikut ini adalah uraian data yang telah didapat:

Tabel 2.

Kualitas Produk Hasil Validasi Oleh Ahli Materi

\begin{tabular}{ccc}
\hline No & Aspek yang Dinilai & Persentase \\
\hline 1 & Kualitas & $100 \%$ \\
2 & Isi & $96 \%$ \\
\hline \multicolumn{3}{c}{ Rata-rata Persentase } \\
Kategori & $98 \%$ \\
& Sangat Baik \\
\hline
\end{tabular}

Hasil penilaian dari ahli materi pembelajaran untuk aspek kualitas materi pembelajaran diperoleh persentase $100 \%$ dan kategori Sangat Baik. Sedangkan pada aspek isi materi pembelajaran diperoleh skor 50 dengan persentase $96 \%$ dan kategori Sangat Baik. Berdasarkan hasil penilaian dari aspek kualitas dan isi yang dilakukan oleh ahli materi diperoleh rata-rata persentase sebesar $98 \%$ dengan kategori sangat baik.

\section{Revisi produk}

Hasil evaluasi yang dilakukan oleh ahli desain pembelajaran dari produk Rencana Pelaksanaan Pembelajaran (RPP), menyarankan beberapa hal yang perlu direvisi terkait dengan aspek kualitas dan aspek isi Rencana Pelaksanaan Pembelajaran (RPP). Berikut ini adalah beberapa saran yang perlu diperhatikan antara lain: (1) ada salah istilah, yakni religiusitas, nasionalisme, kemandirian, gotong royong dan integritas, (2) komponen media dan sumber belajar ditambahkan, (3) perbaikan bahasa, (4) perbaikan salah ketik, (5) nilai-nilai karakter sebagai dampak pengiring harus terdapat dalam kegiatan pendahuluan, kegiatan inti dan kegiatan penutup sesuai dengan kompetensi inti.

Hasil evaluasi yang dilakukan oleh ahli materi dari produk Rencana Pelaksanaan Pembelajaran (RPP), menyarankan beberapa hal yang perlu direvisi terkait dengan aspek kualitas dan aspek isi Rencana Pelaksanaan Pembelajaran (RPP). Berikut ini adalah beberapa saran yang perlu diperhatikan antara lain: (1) ditambahkan komponen materi pembelajaran yang sesuai dan diperdalam materinya, (2) untuk kegiatan pembelajaran nilai-nilai karakternya harus lebih konkret pada pengalaman belajar yang berhubungan dengan pembiasaan dan budaya sekolah.
Setelah mendapatkan masukan dan saran dari dua ahli desain pembelajaran dan ahli materi maka langkah selanjutnya yaitu melakukan revisi produk.

Revisi produk yang dilakukan pada draf produk awal diantaranya sebagai berikut:

1. Mengganti istilah "religius" menjadi "religiusitas, "nasionalis" menjadi "nasionalisme" dan "mandiri" menjadi "kemandirian".

2. Mengganti "SDN [...]" pada nama sekolah di identitas RPP menjadi "SD [...]".

3. Mengganti tulisan "kelas 2" di tujuan dan media pembelajaran, menjadi "kelas II".

4. Memperbaiki salah ketik pada Kompetensi Inti (KI) 3 dan 4 .

5. Menambahkan komponen "Materi Pembelajaran" di RPP. Komponen tersebut berisi materi yang sesuai dengan Kompetensi Dasar (KD) dan Indikator Pencapaian Kompetensi.

6. Menambahkan media pembelajaran dan sumber belajar, yakni (1) gambar Kerukunan Keluarga di Rumah, (2) gambar Kelompok Buku dan Kubus, (3) teks percakapan.

7. Menambahkan dan mengubah kegiatan pembelajaran di kegiatan pendahuluan. Kegiatan guru menanyakan kabar siswa yang semula dilakukan setelah memberikan salam diubah menjadi setelah guru memberikan bimbingan mengenai pentingnya memulai sesuatu dengan berdoa dan kegiatan menanyakan kabar siswa dilakukan sambil guru mengecek kehadiran siswa. Selain itu penambahan kegiatan yang berbasis budaya lingkungan sekolah, yakni dengan menambahkan kegiatan keagamaan sesuai dengan basis lingkungan sekolah.

8. Menambahkan kegiatan pembelajaran di kegiatan inti, yakni dengan memberikan latihan kepada siswa mengenai bilangan cacah dengan tiga angka.

9. Menambahkan kegiatan pembelajaran di kegiatan penutup, yakni dengan menambahkan kegiatan siswa berpamitan dengan guru sambil mencium tangan.

10. Mengubah karakter yang dikembangkan. Semula dalam draf produk, pada kolom karakter yang dikembangkan, karakter yang tertulis di kolom tersebut bukan saja karakter menurut Penguatan Pendidikan Karakter (PPK) tetapi juga tertulis karakter luhur lain. Namun menurut masukan dan saran dari ahli desain pembelajaran, karena yang diobservasi pada siswa diakhir hanya 5 karakter menurut Penguatan Pendidikan Karakter (PPK) maka sebaiknya karakter lain tidak perlu ikut tertulis. Oleh karena revisi dilakukan hanya 
dengan menuliskan 5 karakter saja yakni karakter menurut nilai-nilai utama Penguatan Pendidikan Karakter (PPK).

11. Mengubah alokasi waktu, yang awalnya untuk kegiatan pendahuluan 15 menit berubah menjadi 20 menit, kegiatan inti berubah dari 175 menit menjadi 170 menit.

Revisi produk dilakukan sesuai masukan dan saran yang diberikan para ahli. Revisi ini memberikan beberapa perubahan terhadap produk yang dikembangkan, Setelah direvisi sesuai masukan dan saran dari para ahli, produk Rencana Pelaksanaan Pembelajaran (RPP) kemudian di uji coba dalam kelompok kecil.

\section{Uji coba skala kecil}

Uji empirik kelompok kecil dilakukan pada 6 orang guru Sekolah Dasar (SD) yang ada di SD Muhammadiyah 24 Jakarta Timur. Uji empirik dilakukan dengan memberikan kuesioner yang berisi penilaian aspek kualitas materi pembelajaran dan aspek isi materi pembelajaran. Guru diberikan contoh Rencana Pelaksanaan Pembelajaran (RPP) dan angket untuk memberikan penilain terhadap Rencana Pelaksanaan Pembelajaran (RPP) yang telah dikembangkan. Sebelum pengisian angket terlebih dahulu peneliti menjelaskan mekanisme pengisian angket dan memperlihatkan produk Rencana Pelaksanaan Pembelajaran (RPP). Setelah itu, semua guru dipersilakan memberikan skor terhadap aspekaspek yang ada di dalam angket. Setelah semua guru selesai mengisi angket, apabila ada saran dan komentar mengenai Rencana Pelaksanaan Pembelajaran (RPP) yang dikembangkan dipersilahkan untuk disampaikan secara tertulis pada bagian lembar angket. Berikut ini adalah hasil pengolahan data pada uji coba kelompok kecil dari aspek kualitas dan isi materi pembelajaran.

Tabel 3.

Kualitas Produk Hasil Hasil Uji Coba Skala Kecil

\begin{tabular}{ccc}
\hline No & Aspek yang Dinilai & Persentase \\
\hline 1 & Kualitas & $91 \%$ \\
2 & Isi & $88 \%$ \\
\hline \multicolumn{3}{c}{ Rata-rata Persentase } \\
Kategori & $90 \%$ \\
& Sangat Baik \\
\hline
\end{tabular}

Hasil penilaian dari uji coba kelompok kecil untuk aspek kualitas materi pembelajaran diperoleh persentase 91\% dan kategori Sangat Baik. Sedangkan pada aspek isi materi pembelajaran diperoleh persentase $88 \%$ dan kategori Sangat Baik. Berdasarkan persentase yang di dapat pada aspek kualitas dan aspek isi uji coba kelompok kecil diperoleh rata-rata persentase sebesar 90\% dengan kategori sangat baik.

\section{Produk akhir.}

Hasil uji coba kelompok kecil dari produk Rencana Pelaksanaan Pembelajaran (RPP) yang dilakukan kepada 6 orang guru, menyarankan beberapa hal yang perlu direvisi terkait dengan aspek kualitas dan aspek isi Rencana Pelaksanaan Pembelajaran (RPP). Berikut ini adalah saran yang perlu diperhatikan yakni alangkah lebih baik jika media pembelajarannya lebih beragam dan lebih kreatif di dalam Rencana Pelaksanaan Pembelajaran (RPP).

Setelah mendapatkan masukan dan saran dari 6 orang guru sebagai uji coba kelompok kecil maka langkah selanjutnya yaitu melakukan revisi produk untuk yang kedua kali. Revisi produk dilakukan sesuai masukan dan saran yang diberikan oleh guru. Revisi yang kedua yang dilakukan diantaranya adalah:

1. Menambahkan media pembelajaran dan sumber belajar. Media pembelajaran yang ditambahkan adalah Lembar Kerja Siswa (LKS) berbasis Multiple Intelligence (SLIM-N-BIL).

2. Menambahkan lampiran Lembar Kerja Siswa (LKS) berbasis Multiple Intelligence (SLIM-N-BIL) di akhir RPP.

3. Spatial Intelligence = Siswa diberikan gambar mengenai kerja bakti di rumah, lalu siswa diminta memperhatikan gambar tersebut dan menuliskan sikap yang dapat menjaga kerukunan di rumah apabila sedang melakukan kerja bakti.

4. Linguistic Intelligence = Siswa diberikan gambar mengenai keluarga yang sedang berbincang dengan rukun satu sama lain, siswa diminta untuk mengamati gambar tersebut dan membuat teks percakapan berdasarkan gambar yang sudah diamati.

5. Interpersonal Intelligence $=$ Siswa diberikan teks percakapan, siswa diminta bermain peran dengan anggota keluarga di rumah berdasarkan teks percakapan tersebut.

6. Musical Intelligence $=$ Siswa diberikan teks lirik lagu nasional beserta notasi nadanya. Siswa diminta membuat kelompok sebanyak 4 orang, 2 orang siswa menyanyikan lagu sesuai panjang pendek nada, dan 2 orang siswa lain mengiringi temannya menggunakan alat musik pianika.

7. Naturalist Intelligence $=$ Siswa diminta mengunjungi tempat wisata yang berhubungan dengan alam bersama anggota keluarga. Siswa diminta mengabadikan hasil kunjungan tersebut ke dalam bentuk foto dan menempelkan di kolom yang telah tersedia.

8. Bodily-Kinesthethic Intelligence $=$ Siswa diminta 
bermain, satu orang menjadi sutradara, siswa lain menjadi pemain. Sutradara bertugas untuk mengarahkan pemain melakukan beberapa kegiatan sambil menyanyikan lagu "Satu-satu Aku Sayang Ibu"

9. Intrapersonal Intelligence $=$ Siswa diminta merefleksikan diri mengenai dirinya dan anggota keluarganya dengan menjawab beberapa pertanyaan yang sudah disediakan.

10. Logical-Mathematical Intelligence = Siswa diminta mengamati huruf-huruf yang ada pada kalimat "Hidup Rukun di Rumah" lalu siswa diminta menjawab mengenai jumlah huruf tertentu di dalam kalimat tersebut. Selain itu siswa diminta mengamati gambar tumpukan buku yang ada di rak, lalu siswa diminta menghitung jumlah buku yang ada pada masing-masing rak.

11. Setelah melakukan revisi, maka produk akhir dari penelitian dan pengembangan ini adalah prototipe Rencana Pelaksanaan Pembelajaran (RPP) tematik berbasis karakter menurut Penguatan Pendidikan Karakter (PPK) yang terdiri dari karakter religiusitas, karakter nasionalisme, karakter kemandirian, karakter gotong royong, dan karakter integritas.

\section{PENUTUP}

\section{Kesimpulan}

Produk akhir dari penelitian ini adalah prototipe Rencana Pelaksanaan Pembelajaran (RPP) tematik berbasis karakter menurut Penguatan Pendidikan Karakter (PPK) yang terdiri dari karakter religiusitas, karakter nasionalisme, karakter kemandirian, karakter gotong royong, dan karakter integritas. Hasil validasi ahli desain pembelajaran mendapat penilaian pada aspek kualitas sebesar 77\% dan aspek isi materi sebesar $75 \%$ dengan rata-rata sebesar $76 \%$ dan termasuk dalam kategori baik. Hasil validasi ahli materi mendapat penilaian pada aspek kualitas sebesar $100 \%$ dan aspek isi materi sebesar $96 \%$ dengan rata-rata sebesar $98 \%$ dan termasuk dalam kategori sangat baik. Sedangkan hasil uji coba kelompok kecil yang dilakukan kepada 6 orang guru mendapat penilaian pada aspek kualitas sebesar $91 \%$ dan aspek isi materi sebesar $88 \%$ dengan rata-rata sebesar $90 \%$ dan termasuk dalam kategori sangat baik. Hasil tersebut menunjukkan bahwa produk prototipe Rencana Pelaksanaan Pembelajaran (RPP) tematik yang dikembangkan dapat diterima dan diterapkan dalam proses pembelajaran pada siswa kelas 2 Sekolah Dasar (SD) sehingga diharapkan dapat memberikan dampak pengiring yang akan menghasilkan karakter religiusitas, nasionalisme, kemandirian, gotong royong dan integritas.

\section{Saran}

Beberapa hal yang dapat direkomendasikan dari penelitian ini adalah:

1. Apabila lembaga sekolah mengadopsi program Penguatan Pendidikan Karakter (PPK) yang diintegrasikan dengan proses pembelajaran, sebaiknya guru membuat Rencana Pelaksanaan Pembelajaran (RPP) yang sesuai dan tepat agar proses pembelajaran yang akan dilaksanakan dapat membentuk karakter yang diharapkan dan karakter tersebut nantinya dapat terukur dengan baik dengan penilaian yang sesuai.

2. Peneliti selanjutnya ataupun guru sebaiknya dapat melakukan penelitian modifikasi sehingga dapat membuat produk serupa atau melakukan pengembangan lanjutan dari produk sehingga produk tersebut dapat dilanjutkan ke uji coba pemakaian.

\section{DAFTAR PUSTAKA}

Djiwandono, Sri Esti Wuryani. (2006). Psikologi Pendidikan. Jakarta: Grasindo.

Kawuryan, Sekar Purbarini. (2017). Karakteristik Siswa SD Kelas Rendah dan Pembelajarannya. Artikel. Diambil dari http://staffnew.uny.ac.id/upload/132313274.

Samani, Muchlis dan Hariyanto. (2012). Konsep dan Model Pendidikan Karakter. Bandung: PT. Remaja Rosdakarya.

Sugiyono. (2018). Metode Penelitian Kuantitatif, Kualitatif dan RED. Bandung: Alfabeta.

Surya, Anesa, Sularmi, Siti Istiyati, dan Rahmat Fajar Prakoso. (2018). Finding Hots-Based Mathematical Learning In Elementary School Student. Artikel. Diambil dari https://jurnal.uns.ac.id. Wibowo, Agus. (2012). Pendidikan Karakter Strategi Membangun Karakter Bangsa Berperadaban. Yogyakarta: Pustaka Pelajar. 
Pengembangan Rencana Pelaksanaan...

42 PERSPEKTIF Ilmu Pendidikan - Vol. 34 No.1 April 2020 